\title{
TRZY FALE \\ EMANCYPACJI HOMOSEKSUALNEJ \\ W POLSCE
}

\author{
BŁAŻEJ WARKOCKI ${ }^{1}$ \\ (Uniwersytet im. Adama Mickiewicza w Poznaniu)
}

Słowa kluczowe: queer, gender, emancypacja LGBT, literatura polska po 1989

Keywords: queer, gender, LGBT emancipation, Polish literature since 1989

\begin{abstract}
Abstrakt: Błażej Warkocki, TRZY FALE EMANCYPACJI HOMOSEKSUALNEJ W POLSCE. „PORÓWNANIA” 15, 2014, T. XV, s. 121-132. ISSN 1733-165X. Artykuł przedstawia trzy fale emancypacji gejowsko-lesbijskiej w Polsce - jako kraju pół-peryferii. W związku z tym kontekstem rozważań staje się emancypacja na Zachodzie. Jednak głównym celem jest przedstawienie rodzimych aktywności emancypacyjnych za pomocą słów i pojęć używanych przez jej uczestników. Z tego też punktu widzenia przedstawiona zostaje transformacja (wyobrażonej) tożsamości zbiorowej. Te trzy fale zazębiają się z kolejnymi dekadami: lata 80-te, 90-te i po roku 2003. Literatura polska tego okresu czasu jest przedstawiona jako swoiste lustro procesów społecznych (od utworów Juliana Stryjkowskiego i Mariana Pankowskiego z lat 80-tych po współczesne dzieła Michała Witkowskiego i Pawła Demirskiego).
\end{abstract}

\begin{abstract}
Błażej Warkocki, THREE WAVES OF HOMOSEXUAL EMANCIPATION IN POLAND. "PORÓWNANIA" 15, 2014, Vol. XV, p. 121-132. ISSN 1733-165X. The article presents three waves of LGBT emancipation in Poland, as the country of semi-periphery. Therefore, western emancipation is also included in the debate. However, the main goal is to describe emancipation in the terms which have been used by the participants of that process. And from that point of view, the article characterizes the transformation of (the imagined) collective identity. From the 80 's, through the 90 's, but also after 2003. I present how the project of "gay identity" was applied. Polish literature is used here as a mirror of emancipation (from Julian Stryjowski and Marian Pankowski to Michał Witkowski and Paweł Demirski).
\end{abstract}

${ }^{1}$ Correspondence Address: warkocki@amu.edu.pl 
Emancypacyjne dyskursy LGBT stają się dziś jednym z ważniejszych symptomów na globalnej mapie zależności, w tym postkolonialnych i neokolonialnych². Mogą być przedstawiane jako znak nowoczesności bądź zacofania danego społeczeństwa. Mogą być „innym” dyskursu narodowego, wręcz jego obiektem nienawiści, ale mogą czasami być instrumentalnie wykorzystywanym elementem dyskursu narodowego - którego właściwym celem jest pognębienie jakiejś innej mniejszości, na co wskazywała chociażby Judith Buttler w książce Ramy wojny. Kiedy życie jest godne opłakiwania?3. Ostatnio coraz wyraźniej stają się budulcem do konstruowania dystynkcji Wschód-Zachód. Być może jesteśmy w newralgicznym momencie tego procesu. Unia Europejska wspiera legalizację związków jednopłciowych, Unia Euroazjatycka przywoływana przez Władimira Putina, wspierałaby raczej jakiś rodzaj zakazu tzw. propagandy homoseksualnej.

Z całą pewnością nie należy esencjalizować stosunku różnych społeczeństw do kwestii gejowsko-lesbijskiej. Dlatego pozwolę sobie uhistorycznić emancypację w Polsce i wskazać na, co najmniej trzy dekady homoseksualnego/gejowskiego aktywizmu. Swoistym kontrapunktem tej konceptualizacji będzie wizja przedstawiona w książce De-centring Western Sexualities. Central and Eastern European Perspectives pod redakcją Joanny Mizielińskiej i Roberta Kulpy (zwłaszcza w ich własnym artykule: Contemporary Peripheries: Queer Studies, Cerciulation of Knowledge and East/West Divide) $)^{4}$. Zgodnie z przedstawioną tam wizją, zachodnie i wschodnie "geo-temporalne modalności" mają się różnić tym, że zachód to "czas sekwencji” a wschód "czas jednoczesności", gdzie wszystkie etapy emancypacji pojawiają się jednocześnie. Chciałbym nadkruszyć tę esencjalizującą wizję i uhistorycznić dyskurs emancypacyjny. Nie chodzi jednak o opis „zapóźnień” w stosunku do Zachodu, lecz raczej o uchwycenie specyfiki lokalnej dynamiki emancypacyjnej.

Jej rekonstrukcja nie należy do rzeczy najprostszych, ponieważ polska instytucjonalna historiografia prawie $\mathrm{w}$ ogóle nie zajmuje się historią $\mathrm{w}$ kontekście homoseksualności. Jest to zdecydowanie biała plama. A przecież Polska jest ogromnie wdzięcznym tematem rozważań. Doczekała się ona bowiem bardzo liberalnego kodeksu karnego (z 1932 roku), który dekryminalizował stosunki seksualne pomiędzy dorosłymi osobami. Jednak, jak pisze karnistka prof. Monika Płatek, pomimo tak liberalnego (na tle innych krajów europejskich) prawa, pewien rodzaj penalizacji pozostał pod postacią kary za homoseksualną prostytucję. A za korzyść świadcząca o prostytucji mogło być uznane na przykład zaproszenie do kawiarni czy teatru. Jednak ten zapis został wykreślony z kodeksu karnego z 1969 roku,

2 J. K. Puar, Terrorist assemblanges. Homonationalism in queer times. Duke University Press 2007.

3 J. Butler, Ramy wojny. Kiedy życie jest godne optakiwania? Przeł. A. Czarnacka. Warszawa 2011.

${ }^{4}$ J. Mizielińska, R. Kulpa, Contemporary Peripheries: Queer Studies, Circulation of Knowledge and East/West Divide. W: De-centring Western Sexualities. Central and Eastern European Perspectives. Red. J. Mizielińska, R. Kulpa. Ashgate 2011. 
który wszedł w życie w 1970. A zatem, przynajmniej teoretycznie, w PRL-u dokonała się całkowita depenalizacja relacji seksualnych pomiędzy osobami tej samej płci ${ }^{5}$. Na tle europejskim czy amerykańskim prawodawstwo polskie wyglądało zatem bardzo nowocześnie. A jednak - podkreślmy - życie osób nieheteroseksualnych nie mogło wyglądać różowo, bo homoseksualność w codziennym życiu była całkowicie spatologizowana i stabuizowana. I taki stan rzeczy niewątpliwie łączył PRL-owskie władze partyjne z dyskursem Kościoła katolickiego w Polsce. Działalność emancypacyjna nie ośrodkowała się zatem wokół kwestii związanych z seksem (ten bowiem był w Polsce legalny), lecz wokół korpusu spraw, które można by nazwać - w tradycji heglowskiej - „uznaniem” (Anerkennung) ${ }^{6}$ odmiennego, ale godnego życia.

Fale emancypacji zazębiają się z kolejnymi dekadami. Periodyzację można by, w graficznym skrócie, przedstawić następująco:

1981 - 1990 - wczesna faza emancypacji, ,inni"

1990 - 2003 - emancypacja gejowska i lesbijska

2003 - do dziś - widzialność w dyskursie publicznym, polityzacja homofobii, homoseksualista jako obiekt nienawiści dyskursu nacjonalistycznego.

Lata 80-te to rodzaj liberalizacji obyczajowej w PRL oraz nawrót tematów do tej pory wypieranych (wśród nich na przykład kwestia stosunków polsko-żydowskich). Warto zatem zauważyć, że początek lat 80-tych inaugurują dwa utwory, które jawnie tematyzują odmienne (choć podobne) wersje męskiej tożsamości homoseksualnej. Z jednej strony to dłuższe opowiadanie Juliana Stryjkowskiego Tomasso del Cavaliere (1981) oraz krótka powieść Rudolf (1980) pozostającego na emigracji (w Brukseli) Mariana Pankowskiego. Pierwsze opowiada o genialnym artyście Michale Aniele, widzianym oczyma ignorowanego przezeń ucznia; drugie - o spotkaniu przykładnego polskiego profesora z niemieckim homoseksualistą (w polskiej literaturze homoseksualiści często bywali nie-Polakami), który czerpał radość i rozkosz ze swego pozostawania na marginesie społeczeństwa (czym, rzecz jasna, szokował profesora).

Oba te utwory można czytać jako swoiste propozycje egzystencjalne dla homoseksualnych mężczyzn, właściwie jedyne możliwości - bo paleta dostępnych ról była bardzo uboga. W skrócie zatem: Artysta albo Zboczeniec. Kompensacja w sztuce bądź pełne hipokryzji pozostawanie na marginesie wspólnoty. Tertium

${ }^{5}$ M. Płatek, Sytuacja osób homoseksualnych w prawie karnym. W: Orientacja seksualna i tożsamość ptciowa. Aspekty prawne i spoteczne. Red. R. Wieruszewski, M. Wyrzykowski. Warszawa 2009.

${ }^{6}$ Patrz: N. Fraser, A. Honneth, Redystrybucja czy uznanie. Debata polityczno-filozoficzna. Przeł. M. Bobako i T. Dominiak. Wrocław 2005.

${ }^{7}$ Koncepcję "fal emancypacji” przedstawiłem pierwotnie w popularyzatorskim czasopiśmie niemieckojęzycznym. B. Warkocki, Polen unter dem Regenbogen. Die drei Emanzipationswellen der Schwulen in Polen. "Jahrbuch Polen" 2014. Zarys koncepcji pojawił się w mojej książce: B. Warkocki, Różowy jezzyk. Literatura i polityka kultury na początku wieku. Warszawa 2013. 
non datum. Literatura przełomu lat 80-tych i 90-tych (choćby W ptaszarni Grzegorza Musiała, Ból istnienia Marcina Krzeszowca czy Grecki bożek Marka Nowakowskiego) pokazywała jak dalece niewystarczająca jest to paleta możliwości. Szczególnie znacząca jest tu powieść Krzeszowca. Jego powieściowy bohater nie jest ani Artystą ani Zboczeńcem. Krzeszowiec przedstawia - rodzącą się w prawdziwych bólach - nowa propozycję egzystencjalną i tożsamościową: geja. Tym samym inaugurując nową dekadę (powieść powstała pod koniec lat 80-tych, a ukazała się w 1992).

Tak kwestia tożsamości wyglądałaby od strony literatury. Trzeba jednak pamiętać, że lata 80. to wiele śladów wzmożonego zainteresowania tą tematyką. Z perspektywy historycznej rzecz zbadała Agata Fiedotow w artykule Początki ruchu gejowskiego w Polsce (1981-1990)8. Nade wszystko coś zmieniło się w dyskursie publicznym. Jak podaje autorka, temat homoseksualności pojawiał się w okresie 1981-1989 roku około 100 razy; to niewiele w stosunku do tego, co pojawiło się w samym roku 1990, ale bardzo wiele w stosunku do tego, co pojawiało się przed latami 80. Trzeba wspomnieć tu zwłaszcza reportaż Barbary Pietkiewicz Gorzki fiolet z 1981 publikowany w "Polityce”, a zatem w mainstreamowym, powszechnie czytanym tygodniku.

Warto również wymienić artykuł Krzysztofa Darskiego (pod tym pseudonimem wystąpił Dariusz Prorok) pod charakterystycznym tytułem Jesteśmy inni, również z „Polityki” (1985), będący właściwie pierwszym polskim gejowskim manifestem emancypacyjnym. Zacytujmy fragment:

Ośmieszani i spychani na margines społeczeństwa, dyskryminowani przez wszystkie bez wyjątku instytucje i organizacje społeczne, tępieni przez homofobów, bici i obrzucani obelgami przez chamów przy milczącej zgodzie autorytetów tego świata, osamotnieni i porzuceni przez państwo, kościół, naukę [...]. Czy homoseksualiści mają jakiekolwiek prawa w naszym kraju? Czy ktokolwiek zainteresowany jest w pomaganiu im w ich jakże oczywistych kłopotach osobistych? Czy komuś zależy na podtrzymywaniu trwałości związku dwóch mężczyzn? ${ }^{9}$

Jedną z bardziej tajemniczych kwestii dotyczących homoseksualnych mężczyzn w PRL była ogólnopolska akcja pod kryptonimem „Hiacynt” wymierzona w to środowisko, która miała miejsce na pod koniec 1985 roku (i była powtarzana jeszcze kilkakrotnie), przeprowadzana przez Milicję Obywatelską oraz (prawdopodobnie) Służby Bezpieczeństwa. Ciągle niewiele wiadomo na temat tej akcji. Choć w Polsce okres PRL-u jest badany dość intensywnie (nawet samochód marki „Syrenka" ma swą osobną monografię) to prześladowania homoseksualistów

${ }^{8}$ A. Fiedotow, Początki ruchu gejowskiego w Polsce (1981-1990). W: Ktopoty z seksem w PRL. Rodzenie nie całkiem po ludzku, aborcja, odmienności. Red. M. Kula, Warszawa 2012.

${ }^{9}$ K. T. Darski, Jesteśmy inni. „Polityka” 1985, nr 47, s. 8. 
ciągle nie doczekały się osobnej kompetentnej pracy historycznej. A skądinąd wiadomo, że niemal przez cały okres PRL-u Służby Bezpieczeństwa inwigilowały homoseksualnych mężczyzn (wśród niech z całą pewnością takich jak: Jarosław Iwaszkiewicz, Jerzy Andrzejewski czy Michel Foucault) jak również dokonywano spisów homoseksualistów. Akcja "Hiacynt” mogła być intesyfikacją tych działań, mogła mieć za zadanie specyficznie rozumianą prewencję HIV/AIDS, mogła być próbą stłumienia pierwszych inicjatyw gejowskich.

Kim jednak byli seksualni odmieńcy ósmej dekady? Jak siebie postrzegali, jak definiowali? Praca Agaty Fiedotow dostarcza tu ciekawego materiału. Okazuje się bowiem, że działacze skupieni wokół stowarzyszenia International Gay Association (IGA) ${ }^{10}$ utworzyli specjalną komórkę do kontaktów z krajami bloku komunistycznego - East Europe Infomation Pool (EEIP), która miała gromadzić informacje na temat sytuacji prawnej i społecznej osób homoseksualnych oraz nawiązywać kontakty. EEIP utworzono przy zrzeszonej z IGA austriackiej organizacji Homosexuele Initiative Wien (HOSI), a koordynatorem został Polak mieszkający w Wiedniu Andrzej Selerowicz. Być może dlatego kontakty z Polską były najbardziej intensywne.

Fiedotow przeanalizowała około 280 listów pisanych w latach 80 . do przedstawicieli EEIP oraz listy pisane do czasopism młodzieżowych Razem i Na przełaj. Wyłania się z nich dość smutna autobiografia homoseksualistów. Historyczka wskazuje na charakterystyczne toposy: wrogość i nietolerancja otoczenia (również złe warunki bytowe - w skargach kierowanych do organizacji zachodnich), nieustająca obawa, niepokoje, lęki (powtarzający się zatem topos paranoiczny), poczucie osamotnienia, załamania (alkoholizm, depresja, samobójstwo), choć czasami - dużo rzadziej - akceptacja swej seksualności („mnie jest z <tym> dobrze”). Opisuje również strategie ukrycia - od podwójnego życia w małżeńskich związkach heteroseksualnych (jak twierdził Darski - większość homoseksualistów w Polsce była żonata) po samotność jako wybór.

Najciekawszy jednak był projekt społecznej demarginalizacji ze strony EEIP próba aplikacji tożsamości gejowskiej i towarzyszącego mu ruchu do rzeczywistości końca PRL. I ta próba zakończyła się całkowitym fiaskiem, ponieważ rozmijała się z realiami życia w Polsce. Zachodnich działaczy zdziwił zatem opór wobec oddolnych inicjatyw społecznych nie tylko ze strony władz, ale również samych zainteresowanych, którzy nie palili się do formalizowania własnej działalności (które oznaczałoby przecież ujawnienie). Grupy gejowskie bardzo długo zachowywały bowiem charakter głównie towarzyski, w których mówiło się o "naszych sprawach". Nieufność wzbudzało zbieranie adresów kontaktowych do korespondencji. Redaktor biuletynu EEIP stawał się dla odbiorców raczej kimś w rodzaju przyjaciela i doradcy niż potencjalnym przywódcą ruchu gejowskiego. Budowanie

10 Od 1986 jako ILGA - International Lesbian and Gay Association. 
tożsamości gejowskiej (jawność, duma, związki) i świadomości społecznej w kontrze do "homoseksualizmu pikietowego”, czyli opartego na przygodnym seksie zasadniczo się nie powiodło.

Co jednak nie udało się pod koniec lat 80 ., zaczęło być krok po kroku realizowane $\mathrm{w}$ następnej dekadzie. Lata 90 . to bowiem czasy wprowadzania $\mathrm{w}$ życie projektu gejowskiego i stabilizacja tożsamości gejowskiej.

Zacznijmy od początku. Po pierwsze, zmieniona zostało prawo o stowarzyszeniach, zgodnie z którym legalizacja miała należeć do sądów rejonowych, a nie jak dotąd - do władz administracyjnych. W ten sposób w 1990 roku zarejestrowano stowarzyszenie Lambda. $W$ niektórych większych miastach pojawiała się półjawna infrastruktura życia towarzyskiego. I co, zapewne, najbardziej wpływowe w skutkach - pojawiały się czasopisma kierowane do homoseksualistów. Niektóre były dość mocno efemeryczne, inne trwały bardzo długo - jak wydawane w Poznaniu czasopismo „Inaczej” (dwanaście lat). Nie sposób przecenić ich znaczenia. Nie były to pisma pornograficzne, mogły być kolportowane przez „Ruch”, a zatem dostępne były właściwie $w$ całej Polsce. Zapewne nie były sprzedawane na wsiach i w małych miasteczkach, ale i tak można powiedzieć, że dostępne musiały być całkiem nieźle. W ten sposób zapewne odrywały rolę podręcznika do tożsamości gejowskiej.

Właśnie - "gejowskiej”. Warto przez moment zastanowić się nad słowami, którzy zainteresowani stosowali wobec samych siebie, opisując swoją tożsamość. W latach 80. często używano słowa „inny”. W niektórych listach do przedstawicieli EEIP w ogóle nie pojawiało się słowo „homoseksualista”, a jako pozytywne samookreślenie używano właśnie mające zapewne charakter eufemizmu słowo „inny" (,Jestem <inny>", ,jestem <inna>"). Wspomniany powyżej manifest Proroka nosił przecież tytuł "Jesteśmy inni". A poznańskie pismo założone w 1990 nosiło tytuł „Inaczej”. Inność wydaje się zatem kluczem do ówczesnej tożsamości, a jednocześnie pozytywną autodefinicją, przy braku innych niepogardliwych określeń. Pod koniec lat 80. pojawiło się w Polsce słowo "gay". Pierwsze numery czasopism pokazywały nawet dosłownie asymiliację językową tego słowa. Stosowały na przykład przymiotnik "gayowski”, który z czasem zamienił się w "gejowski". Nie było to jednak tylko słowo, lecz cały projekt tożsamościowy, który krył się za tym określeniem i rozwijał przez całe lata 90., i w następnej dekadzie.

Ten projekt jednak także nie doczekał się historyczno-socjologicznego opisu i analizy, mimo że niezbędny materiał jest obfity: numery czasopism, pojawiające się tam dyskusje, jak i liczne listy do redakcji. Byłby to zapewne również ciekawy przyczynek do charakterystyki Polski czasów transformacji. Na kilka jednak rzeczy warto wskazać. Po pierwsze ważna okazywała się amerykańska tradycja emancypacyjna a zwłaszcza "mit Stonewall”, a zatem wydarzenie, które miało być punktem zwrotnym. Wielokrotnie przywoływano te wydarzenia i oczekiwano, że w Polsce mogłoby (ewentualnie: nie mogłoby) wydarzyć się coś podobnego. Dru- 
ga kwestia to swego rodzaju separatyzm pomiędzy gejami i lesbijkami. Stanowili raczej osobne środowiska z osobnymi interesami społecznymi. Swego rodzaju wyrazem tego separatyzmu było pismo „Inaczej” - gejowskie z kilkoma stronami dla lesbijek. A trzeba dodać, ze lata 90. to zapewne coraz wyrazistsza stabilizacja tożsamości lesbijskiej w Polsce. Krystalizację ciągle przedpolitycznej tożsamości lesbijskiej rejestrowała w latach 90. Joanna Mizielińska ${ }^{11}$.

I rzecz najważniejsza - „kwestia homoseksualna” w latach 90. nie przebiła się jako istotna kwestia społeczna do dyskursu publicznego. Dziennikarzom nie przyszłoby zatem do głosować przepytywać polityków z ich stosunku do legalizacji związków partnerskich czy małżeństw. Była to kwestia postrzegana raczej społecznie marginalna i niepolityczna. Wszystko to zmieniło się jednak radykalnie po roku 2003.

Sięgnijmy jeszcze do literatury dziewiątej dekady. Na jej początku zaistniała w Polsce proza quasi-emancypacyjna, zupełnie niezauważona przez krytyków. Wspomnijmy obszerny Ból istnienia Marcina Krzeszowca (1992), Nie znany świat Antoniego Romanowicza (1992), Zakazana miłość Tadeusza Gorgola (1990), Gorace uczynki (1989) Witolda Jabłońskiego. Książki te bywają przygnębiające, bo obrazują spatologizowanie homoseksualizmu w PRL-u (właśnie wtedy powstawały, choć dopiero III RP pozwoliła im w sposób materialny, choć niezauważony - zaistnieć). Ich bohaterowie mówią tak: owszem, jesteśmy homoseksualistami, zobaczcie, jak mamy strasznie (bo, istotnie, mieli), zrozumcie nas zatem (to chyba się jednak nie udało). Przy okazji, powtórzmy, wykrystalizował się nowy byt tożsamościowy gej (a nie modernistyczny homoseksualista).

Polska literatura lesbijska lat 90. nie miała podobnego punktu wybicia. Najwyrazistszą autorką była (i ciągle jest) Ewa Schillig, która w 1998 roku wydała Lustro. To pierwszy polski zbiór opowiadań, w których jako bohaterka zawsze występuje lesbijka (choć nie od początku wiemy która to będzie, co dodaje lekturze sus-

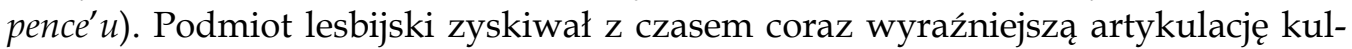
turową i to, co ciekawe, szczególnie $\mathrm{w}$ poezji. Warto $\mathrm{w}$ tym miejscu wymienić tomy: Ewy Sonnenberg Planeta (1997), Ingi Iwasiów Mitość (2000) oraz Izabeli Filipiak Madame Intuita (2002).

Gdyby szukać przełomowej daty, byłby nią zapewne (choć oczywiście umownie) rok 2003. Wtedy to na ulicach kilku polskich miast zawisły plakaty z jednopłciowymi parami w ramach akcji „Niech nas zobaczą". Niestety nie wisiały długo, bo były niszczone. Całość projektu artystycznego Karoliny Breguły można było zobaczyć w kilku galeriach w Polsce. 15 par mężczyzn i 15 kobiet, raczej młodych i z dużych miast, trzymają się za ręce i patrzą nam w oczy. Te portrety wzbudziły ogromną dyskusję i niezwykłe kontrowersje. Były symptomem czegoś nowego:

${ }^{11}$ J. Mizielińska, Lesbianizm w Polsce - pomiędzy świadomością a jej brakiem. „Furia” 1999, nr 1. 
kwestia homoseksualna przebiła się do dyskursu publicznego i stała się polityczna. Z czasem uległa swoistej komercjalizacji.

W tym okresie powstała też nowa organizacja gejowsko-lesbijska Kampania Przeciw Homofobii. Już sama jej nazwa wskazuje na pewną zmianę w myśleniu emancypacyjnym. Problemem przestał być „homoseksualista”, którego normalność należało uzasadniać; $\mathrm{w}$ tej nowej optyce problemem zaczęły być uprzedzenia w stosunku do osób nieheteroseksualnych, czyli homofobia.

Homoseksualność stała się też jednym z zapalnych punktów tożsamości narodowej. I z tej perspektywy - narodowej - homoseksualiści zaczęli być postrzegani jako <obcy> (już nie jako <inni>, jak w latach 80.). Szczególnie wyraziste stało się zwłaszcza w czasie zakazywanych parad równości. Jak pisze na temat Przemysław Czapliński: „W narracji zbiorowej Odmieniec Seksualny przesunął się bowiem z pozycji Innego na pozycję Obcego"12, czego dobitnym przykładem było postępowanie policji 19 XI $2005 \mathrm{w}$ Poznaniu.

Marsz [Równości] został zatrzymany przez kontrpochód - jego uczestniczy krzyczeli m. in. „Pedały do gazu” i „Zrobimy z wami co Hitler z Żydami!”. Policja nie interweniowała $\mathrm{w}$ sprawie antysemickich i homofobicznych okrzyków, za to aresztowała 65 uczestników Marszu. Można powiedzieć, że ci, którzy wznosili okrzyki, testowali swoje prawo do wyznaczenia Obcych - dowiedzieli się, że jest to postępowanie nie tylko dozwolone, ale nawet prawnie chronione ${ }^{13}$.

Istotnie, dla trzeciego etapu emancypacji parady i marsze równości - jako sposób na politykę widzialności - okazały się szczególnie ważne. Trzeba dodać, że początkowo parady nie były mocno zauważane ze strony mediów, dopiero ich zakazy (najpierw w Warszawie przez prezydenta miasta Lecha Kaczyńskiego w 2004), sprawiły, że gejowsko-lesbijska walka o uznanie i równe prawa nabrała medialnej widzialności i stała się kwestią politycznie zapalną. Jednocześnie to wówczas wygenerowała się homofobiczna narracja z homoseksualistą jako Obcym. Jej skrajne wersje widzimy po dzień dzisiejszy. Czasami można wręcz odnieść wrażenie, że współczesny typ homofobii rezydujący w prawicowych mediach przekroczył już wszystkie granice przyzwoitości i przybiera niekiedy postać narracji pogromowej.

Dla tożsamości gejowskiej nowa dekada, zwłaszcza po roku 2003, przyniosła również zmiany. Przede wszystkim dokonywała się powoli rewolucja technologiczna, która dostarczyła nowych, skutecznych narzędzi emancypacyjnych. Internet i jego możliwości zapośredniczył aktywność i nową tożsamość gejowską i lesbijską. Jednocześnie jednak zabił prasę papierową i zanachronizował tworzącą się wokół niej starą tożsamość gejowską z lat 90. (bo po drodze dokonała się też zmia-

\footnotetext{
12 P. Czapliński, „,To ma coś wspólnego z brudem”. „Krytyka Polityczna” 2008, nr 15, s. 119.

${ }^{13}$ Ibidem, s. 119, przypis 3.
} 
na pokoleniowa). Powoli stawał się coraz bardziej widoczny aktywizm transpłciowy, głównie wokół organizacji Tras-fuzja (posłanka Anna Grodzka była wcześniej jej prezeską).

Zaistniała również literatura gejowska i lesbijska, która - inaczej niż ta z poprzedniej dekady - była zauważona, czytana i analizowana, bo kontekst społeczny nadał jej szczególne znaczenie. Szczególne głośne okazało się Lubiewo Michała Witkowskiego (2004), kampowa opowieść o homoseksualistach tęskniących za PRL-em, którzy nie mogą i nie chcą odnaleźć się w nowej kapitalistycznej rzeczywistości. Bo też - jak pokazywały badania - w Polsce nasilało się rozwarstwienie społeczno-ekonomiczne, które coraz mocniej od wewnątrz destabilizowało liberalny podmiot polityki gejowsko-lesbijskiej. Innymi słowy, trudno mówić o spójnej tożsamości gejowskiej czy „obrazie przeciętnego geja”, skoro różnice ekonomiczne i klasowe mają na tę tożsamości wpływ. Różnicują też interesy polityczne.

To zjawisko w pewnym stopniu odzwierciedla literatura trzeciej fali emancypacji. Wydane $\mathrm{w}$ połowie pierwszej dekady nowego wieku roku Lubiewo Michała Witkowskiego (2004) odnosiło się do końca lat 80. i - co może mniej oczywiste, ale dość wyraźne - lat 90. i operowało bardzo wyraźną opozycją tożsamościową "gej versus ciota" budowaną w kontekście polskiej transformacji. Nietrudno zauważyć, że obraźliwe słowo "ciota" w języku polskim - oprócz konotacji z męskim homoseksualizmem - oznacza "frajera”, czyli kogoś, komu się nie powiodło. Można zatem czytać Lubiewo jako opowieść o wygranych i przegranych polskiej transformacji opisywanych językiem quasi-tożsamości homoseksualnych. W tej wersji "geje" to ci, którym się powiodło, potencjalni beneficjenci ustrojowej zmiany. Można tylko ubolewać, że w analizach socjologicznych ta klasowa wyrwa w obrębie tożsamości homoseksualnych (powstająca na tle coraz większego rozwarstwienia ekonomicznego) - rzadko stawał się przedmiotem konstruktywnej refleksji w polskich queer studies.

W paralelnym tekście napisanym prawie dekadę później - w Tęczowej Trybunie 2012 Pawła Demirskiego ${ }^{14}$, który jako swoisty dramat narodowy przeniosła na scenę Monika Strzępka - rzecz wygląda już nieco inaczej. To opowieść budowana z marginesy narodowej wspólnoty - bo niewątpliwie tylko tam mogą się znaleźć geje-kibice piłki nożnej i wielbiciele narodowej drużyny. Sztuka bowiem dotyczy gejów-kibiców domagający się miejsca na trybunie narodowej podczas mistrzostw Euro 2012, które miało miejsce w Polsce. Tu jednak "geje” to raczej przegrani modernizacyjnych złudzeń lat 90., którzy jednak bezustannie (i bezskutecznie) aspirują do wizerunku klasy średniej. Co więcej okazuje się, że - w obrębie neoliberalnej i konserwatywnej hegemonii - interesy gejów kibiców i artysty z klasy wyższej są zdecydowanie różne.

\footnotetext{
${ }^{14}$ Passus interpretujący Tęczowa Trybunę 2012 Pawła Demirskiego publikowałem wcześniej w swojej książce Różowy język. Literatura i polityka kultury na początku wieku. Warszawa 2013.
} 
Tęczowa Trybuna 2012 jest pisana tą szczególną „nadświadomą" frazą Pawła Demirskiego, jakby po lekcji Masłowskiej, gdzie „ucho decyduje o stylu”, a "do dyskursu wkrada się poezja"15. Jest też sztuką zdecydowanie polityczną. Grupa kibiców chce stworzyć własne miejsce, gdzie mogliby być sobą i czuć się bezpiecznie. Chcą tęczowej i wolnej trybuny. I słowo "trybuna” brzmi tu bardzo symbolicznie, przez co całość działań grupy wygląda jak alegoria. Alegoria działań wszelkich grup emancypacyjnych w Polsce. Co robią? Cóż, żyją przecież w wolnej i demokratycznej Polsce z takim poświęceniem wywalczonej przez ojców i matki.

Szybko okazuje się, że ich walka o wolność nie jest jednak dalszą częścią opowieści o walce o wolność ze złą komuną. Na scenie widzimy projektor z zadymami marszowymi i tymi z lat 80.-tych. Co więcej - bohaterowie podczas własnych działań zaplątują się nieopacznie $\mathrm{w}$ rekonstrukcje pałowania $\mathrm{z}$ lat 80., którą zorganizowała na inauguracje lotniska, jedna z głównych bohaterek negatywnych, Prezydent Hania. A Urzędnik poucza:
jest naszą namiętnością
rekonstruowanie demonstracji z lat minionych
czemu się podczepiasz pod nieswoją demonstrację?
to jest nasza demonstracja historyczna $\mathrm{z}$ lat osiemdziesiątych
kiedy było przeciwko demonstrować
specjalnie przygotowana na mistrzostwa europy
żeby zagraniczni kibice wiedzieli jak kiedyśs polska wyglądała ${ }^{16}$

Wymowa fragmentu jest oczywista: wczorajsi opozycjoniści są często dzisiejszymi opresorami. W związku z tym scena rozbijania demonstracji gejowskiej, kiedy aktorzy w zwolnionym tempie przewracają się i cofają, wyglądała jak jedna wielka ironia romantyczna.

Tęczowa Trybuna 2012 świetnie podsumowuje tak działania emancypacyjne, jak również reakcje na te działania. Zwłaszcza w kończącym sztukę ambiwalentnym monologu Ikony, wyraźnie stylizowanym na słynny monolog Roya Cohna z Aniołów w Ameryce Tony'ego Kushnera. Cohn był tam czarnym charakterem, homoseksualistą na szczytach władzy, promotorem konserwatywnego wizerunku i absolutnej hipokryzji - a jednocześnie największym aktywnym homofobem. Ikona jest jednym z chłopaków z grupy, który - rekontekstualizując monolog Cohna - podsumowuje działania Tęczowej Trybuny. A jednocześnie, w cyniczny sposób, w alegorycznym skrócie podsumowuje aktywność wszelkich homoseksualnych grup emancypacyjnych, które zawierzyły regułom demokracji w Polsce.

\footnotetext{
${ }^{15}$ Anna Wojciechowska, Wróżenie z pisma. Nad fraza "Tęczowej Trybuny 2012”. „Notatnik Teatralny" 2012, nr 62-63, s. 36.

${ }_{16}$ P. Demirski, Tęczowa Trybuna 2012. W: Program przedstawienia Tęczowa Trybuna 2012, Teatr Polski we Wrocławiu. Wrocław 2011, s. 120. Prapremiera odbyła się 5 III 2011.
} 
bo pedały to nie są mężczyźni którzy walą się z innymi mężczyznami homoseksualiści to mężczyźni którzy w czasie 15 lat próbowania nie mogli otrzymać antydyskryminacyjnych ustaw od rządu homoseksualiści to ludzie którzy nikogo nie znają i nikt nie zna ich z zerową siłą przebicia i kurwa zerowym wyciągiem z konta kiedy się kończy miesiąc czy to brzmi jak opis mojej kurwa osoby?

nie

mam siłę przebicia

nie sprawdzam nerwowo konta czy jeszcze coś na nim mam bo wiem że mam

i nie czepiam się kurwa żadnej rady dzielnicy ani rady miasta ani kurwa żadnych innych palantów

którzy nie są po to żebym ja im coś mógł od nich chcieć

bo wiem że i tak to się nie uda

a ja nie chcę być przez to że mi się coś nie udało pedałem ${ }^{17}$

Ikona cynicznie podsumowuje efekty emancypacji po 1989 roku a zarazem jakość demokracji. Jednocześnie dochodzi tu do charakterystycznego przesunięcia semantycznego. Tego, którym gra się w wielu miejscach spektaklu. „Homoseksualista”, "pedał” czy inne synonimy miewają różne, zależne od kontekstu, znaczenia. Dwuznaczność semantyczna tego obraźliwego słowa nicuje zastane kategorie i przekierowuje na inne dystynkcje społeczne:

więc ja nie jestem pedałem

ja jestem po prostu człowiekiem

i nie będę się kurwa pchał z wami na żadne kurwa stadiony

bo po prostu robię robię jeden telefon

i mam kurwa miejsce w loży vip na każdy mecz reprezentacji [...]

bo wszyscy tam w loży vip jesteśmy po prostu ludźmi

po prostu ludźmi których na to stać żeby się tym nie interesować

po prostu człowiekiem [...]

człowiek kurwa to jest ważna uniwersalna sprawa na którą trzeba sobie móc pozwolić chcecie się z kibolami zrównać którym kurwa ceny biletów tak podnieśli

żeby na stadiony nie móc wejść $\mathrm{z}$ brudasami kurwa to proszę bardzo

jak was na człowieczeństwo na stadionie nie stać

to stójcie sobie pod stadionem

pedały $^{18}$

W ostatnim paradoksalnym wykrzyknieniu Ikona wyzywa własnych przyjaciół od „pedałów”, gdzie jednak nie znaczy to „homoseksualiści”, ale - „nieudacznicy". Emancypacyjna i konsekwentna walka o uznanie została rozerwana przez

\footnotetext{
17 Ibidem, s. 124.

18 Ibidem, s. 125.
} 
mechanizmy ekonomiczne i struktury klasowe. Polski Cohn mówi wprost, że wobec braków w demokracji i w obliczu rozwarstwienia ekonomicznego jako wyniku działań neoliberalnej ekonomii - gejowską wolność bycia sobą (tak jak wszystko inne) trzeba sobie kupić.

Spektakl można zatem odczytać jako krytykę dyskursu neoliberalnego w Polsce. Dziś jednak znaczenie pierwszorzędne ma z pewnością dyskurs narodowokatolicki. Gdy przyjrzeć się jego głównym emanacjom - takim jak podpalenie pracy Judyty Wójciak „Tęcza” podczas Marszu Niepodległości 2013, czy szeroko zakrojonej ofensywie ideologicznej nazwanej „walką z ideologią gender" (która ewidentnie miała homofobiczny podtekst i agendę), poszukiwaniu "homoseksualnego lobby" w teatrze (albo strukturach Kościoła katolickiego) czy też działaniom i wypowiedziom polskich narodowców - szybko zauważymy, że homoseksualiści są konstruowani jako Obcy narodowo, a jednocześnie politycznie użyteczny obiekt nienawiści. Jednocześnie nietrudno zinterpretować te wydarzenia jako swoisty backlash, konserwatywna reakcję, która bardzo mocno - bo w odwrócony sposób - uwypukla osiągnięcia emancypacji homoseksualnej w Polsce.

Tak oto przeszliśmy od niewidzialności gejów i lesbijek do widzialności; od fazy przedpolitycznej do upolitycznienia homoseksualności i homofobii; od liberalnego podmiotu emancypacji - do jego krytyki. Jedno wszelako jest pewne: wiele jeszcze przed nami. 